\title{
Similar feeding habits of two morphs of Munida gregaria (Decapoda) evidence the lack of trophic polymorphism
}

La similitud en hábitos alimentarios entre morfos de Munida gregaria (Decapoda) evidencia la falta de polimorfismo trófico

\section{Patricia Pérez-Barros ${ }^{1,2}$, M. Carolina Romero', Javier A. Calcagno $^{2}$ and Gustavo A. Lovrich ${ }^{1}$}

${ }^{1}$ Centro Austral de Investigaciones Científicas (CADIC) - CONICET, Houssay 200, V9410CAB Ushuaia, Tierra del Fuego, Argentina

${ }^{2}$ Departamento de Ecología, Genética y Evolución, Facultad de Ciencias Exactas y Naturales, Universidad de Buenos Aires, Pabellón II, Ciudad Universitaria, C1428EHA Buenos Aires, Argentina - CONICET. patopb@yahoo.com

Resumen. - Munida gregaria y M. subrugosa fueron originalmente descritas como especies diferentes, pero estudios recientes evidenciaron que ambas especies constituyen una misma especie biológica, y por tanto son referidas como dos morfos de M. gregaria: 'gregaria' y 'subrugosa'. A pesar de su reciente sinonimia taxonómica, la ocurrencia en simpatría de dos morfos representa un caso interesante para estudiar los procesos involucrados en el mantenimiento de los mismos en la naturaleza. Nuestra hipótesis es que las diferentes morfologías de los apéndices bucales de ambos morfos pueden estar relacionadas con hábitos alimentarios diferentes. Se capturaron adultos de M. gregaria, morfos 'gregaria' y 'subrugosa', en el Canal Beagle por medio de lances epibentónicos de arrastre en noviembre de 2004. La superposición dietaria entre los morfos resultó elevada. Ambos ocuparon la misma posición en la trama trófica del Canal Beagle y mostraron los mismos hábitos alimentarios. Como depredadores, se alimentaron principalmente de crustáceos y algas, y como depositívoros ingirieron materia orgánica particulada y organismos unicelulares bentónicos. Sin embargo, la abundancia relativa de crustáceos fue más alta en los estómagos de 'subrugosa' que en los de 'gregaria', una proporción más alta de estómagos de 'gregaria' contenían más algas que los de 'subrugosa', y se encontró una mayor frecuencia de ocurrencia de presas unicelulares en la dieta de 'gregaria'. No obstante estas diferencias, este estudio no provee evidencias que respalden la existencia de un polimorfismo trófico entre los morfos de M. gregaria, al menos sobre la base del hábito alimentario de los adultos.

Palabras clave: cangrejos, langostillas, especiación, Atlántico sudoccidental

\begin{abstract}
Munida gregaria and M. subrugosa were originally described as two different species on the basis of several morphological characters, but recent studies evidenced that both former species constitute the same biological species, so hereafter they are referred to as two morphs of M. gregaria: 'gregaria' and 'subrugosa'. Notwithstanding their synonimization, the occurrence of two sympatric morphs represents an interesting case for the study of the processes involved in the maintenance of these two morphotypes in nature. We hypothesized that the distinct shapes of mouthparts of both morphs may be related to different feeding habits. Adults of M. gregaria, morphs 'gregaria' and 'subrugosa', were collected in the Beagle Channel by epibenthic trawling during November 2004. The trophic niche of both morphs highly overlapped. Both occupied the same trophic position in the food web of the Beagle Channel, showing the same feeding habits. As predators they fed mainly on crustaceans and algae, and as deposit feeders they ingested particulate organic matter and organisms associated with the superficial layer of the sediment. However, the relative abundance of crustaceans was higher in stomachs of 'subrugosa' than in those of 'gregaria', a higher proportion of stomachs of 'gregaria' contained more algae than in 'subrugosa', and a greater frequency of occurrence of unicellular preys was found in the diet of 'gregaria'. Despite these differences, this study provided no evidences to support the existence of a trophic polymorphism between morphs of M. gregaria, at least based on the feeding habit of adults.
\end{abstract}

Key words: crabs, squat lobster, speciation, SW Atlantic 


\section{INTRODUCTION}

Munida gregaria (Fabricius, 1793) and M. subrugosa (Dana, 1852) were originally described as two different species on the basis of several morphological characters (Lagerberg 1906, Tapella \& Lovrich 2006) that supported their separation (Retamal 1981, Boschi et al. 1992, Retamal 2000, Hendrickx 2003). However, the taxonomic debate that took place during the last century between these two morphospecies (Lagerberg 1906, Chilton 1909, Williams 1973, 1980, Bacardit 1986) motivated Pérez-Barros (2008) to conduct several studies to reevaluate their taxonomic species status. During these studies no genetic (PérezBarros et al. 2008), reproductive behaviour or hybrid intrinsic inviability evidences (Pérez-Barros 2008) were found to support the separation of $M$. gregaria and $M$. subrugosa as two different biological species. Recently, Baba et al. (2008) synonimized Munida gregaria and $M$. subrugosa, and considered the latter as a synonym of the former. Therefore hereafter we will refer to both as morphs of M. gregaria: 'gregaria' and 'subrugosa'.

Both morphs of Munida gregaria are distributed on the continental shelves off southern South America, New Zealand and southern Australia (Baba et al. 2008). In Atlantic waters, both morphs occur from the continental slope off Uruguay $\left(35^{\circ} \mathrm{S}\right)$ to Cape Horn $\left(55^{\circ} \mathrm{S}\right)$, including the Islas Malvinas (Falkland Islands). Off the Chilean Pacific coast, the northern limit of their distribution extends to the island of Chiloé $\left(41^{\circ} \mathrm{S}\right.$ ) (Retamal 1981, Boschi et al. 1992). In many locations, as for example the Beagle Channel, Cape Horn, Golfo San Jorge $\left(46^{\circ} \mathrm{S}\right)$ and Otago (New Zealand) both morphs co-occur simultaneously (Williams 1980, Tapella 2002). Notwithstanding their synonimization, the occurrence of two sympatric morphs represents an interesting case for the study of the processes involved in the maintenance of these two morphotypes in nature.

Resource-based or trophic polymorphisms are widespread among vertebrates and have often been proposed as the initial step in sympatric speciation models (Rosenzweig 1978, Skúlason \& Smith 1995, Smith \& Skúlason 1996, Nakano 1999). Squat lobsters display a variety of feeding habits, from predation, to the ingestion of particulate organic matter (POM), with several intermediate situations (Nicol 1932, Cartés 1993). Particularly, M. gregaria morph 'subrugosa' has two different and simultaneous feeding habits: it preys on crustaceans, algae and polychaetes; and also feeds on the POM and organisms associated with the superficial layer of the sediment (Romero et al. 2004). Sediment gathering is mainly performed by the posterior mouthparts: the endopods of maxillipeds 3 , and therefore, having a wider dactylus and propodus would be favorable for a sedimentivorous habit (Garm \& Høeg 2001). The differences found by Tapella \& Lovrich (2006) in the morphology of the dactylus and propodus of the third maxilliped, and of the mandible of $M$. gregaria morphs 'gregaria' and 'subrugosa' made them hypothesize that the wider maxilliped in 'gregaria' may be an adaptation to deposit feeding, while a wider mandible should confer the ability to process larger food portions, giving 'subrugosa' more capacity for foraging or preying.

The aim of this study is to evaluate the possible existence of a differentiation in the trophic niche of both morphs of $M$. gregaria. We hypothesize that the morphologic differences in the mouthparts documented for 'gregaria' and 'subrugosa' may determine different feeding habits. Therefore we expect: (a) a higher frequency of occurrence and/or relative abundance of sediment and POM in stomach contents of 'gregaria'; (b) a higher frequency of occurrence and/or relative abundance of preys in the stomach contents of 'subrugosa'; (c) a lower energetic content of the hepatopancreas of 'gregaria', as a result of its diet based on POM which has a lower energetic content than preys such as algae and crustaceans (Romero 2003); (d) different values of $\delta^{15} \mathrm{~N}$ and $\delta^{13} \mathrm{C}$ for 'gregaria' and 'subrugosa', since the main food items in their diets have different origins, i.e., POM or preys.

\section{Material AND Methods}

\section{FIELD SAMPLING}

Adults of both morphs of Munida gregaria were collected in the Beagle Channel on the $15^{\text {th }}\left(54^{\circ} 51.156^{\prime} \mathrm{S}\right.$; $\left.68^{\circ} 29.503^{\prime} \mathrm{W}\right)$ and $26^{\text {th }}\left(54^{\circ} 51.690^{\prime} \mathrm{S}\right.$; $\left.68^{\circ} 31.926^{\prime} \mathrm{W}\right)$ of November 2004, at 20-40 m depth by an epibenthic trawl of $10 \mathrm{~mm}$ mesh size and $1.7 \mathrm{~m}$ mouth width (see Tapella 2002 for details). Sampling was performed in November since this is the month in which food ingestion by $M$. gregaria morph 'subrugosa' is the highest, and because no differences were found in its diet throughout the year (Romero et al. 2004). Moreover, in November the more diverse and highest food-offer gives an ad libitum scenario (Mendoza \& Nizovoy 2000), so that Munida gregaria could select the diet items they prefer. Hence, the probability of having the same diet items in their stomachs during this time of the year is likely to be the lowest. 
Morph classification was based on the following morphological characters: (1) a wider rostrum base and (2) longer ocular peduncles in morph 'gregaria'; and (3) lateral margins of the carapace that converge to meet its anterior edge at an obtuse angle, (4) slender terminal segment of the endopodite of the third maxilliped, and (5) a kidney-shaped cornea in the morph 'subrugosa' (Lagerberg 1906, Retamal 1981, Boschi et al. 1992, Tapella \& Lovrich 2006). A standard measure of body size, the carapace length (CL), was determined to the nearest 0.01 $\mathrm{mm}$ on all crabs with a digital caliper. In this study all animals were gonadally mature (i.e., CL $>10 \mathrm{~mm}$, Tapella et al. 2002), average CL was $20.4 \pm 2.1 \mathrm{~mm}$ and $21.5 \pm 2.3$ $\mathrm{mm}$ for 'gregaria' and 'subrugosa', respectively. A total of 40 individuals of each morph were immediately fixed in $4 \%$ buffered formalin seawater, and later used to study their stomach contents. Other 73 individuals, 40 'gregaria' and 33 'subrugosa', were frozen at $-18^{\circ} \mathrm{C}$ for the posterior determination of stomach repletion, and the quantification of the content of organic matter in the stomachs and energetic content in the hepatopancreas. Finally, 75 individuals of each morph were used for $\delta^{15} \mathrm{~N}$ and $\delta^{13} \mathrm{C}$ isotopic determinations. In the present study males and females were pooled for further analyses due to the absence of sexual dimorphism in the mouthparts of both morphs and in the diet of adult 'subrugosa' (Romero et al. 2004).

\section{STOMACH REPLETION, QUANTITY OF INGESTED FOOD, AND CONTENT OF ORGANIC MATTER}

Frozen samples (40 'gregaria' and 33 'subrugosa') were used to quantify the amount of ingested food and organic matter (OM) in each stomach. Stomachs were characterized according to their repletion (proportion of volume occupied by food) using an arbitrary scale, as follows: 1 ) repletion index (RI) 0: empty; 2) RI 1: 1-25\%; 3) RI 2: 26-50\%; 4) RI 3: 51-75\%; 5) RI 4: >76\% (Romero et al. 2004). Each stomach was defrosted, blotted, and weighed before and after extracting its contents. The difference between these weights was considered as the weight of the stomach content (SW). Stomach contents were dried at $60^{\circ} \mathrm{C}$ to constant weight, weighed, burned at $450^{\circ} \mathrm{C}$ for $24 \mathrm{~h}$, and ashes weighed to the nearest $0.01 \mathrm{mg}$. The $\mathrm{OM}$ was calculated as the difference between dry and ash weights. Since the ash weight of one stomach content was small for the resolution of our precision balance, up to 3 stomach contents from animals of the same sex and similar size were pooled before burning.

The quantity of ingested food depends of the animal size (Elner \& Lavoie 1983), and therefore SW and OM were standardized by the dry weight (DM) of the whole animal. The DM was calculated from lineal regressions between log DM and log CL according to their sex (see details in Tapella \& Lovrich 2006). In the case of pooled stomach contents, the standardization was done on the basis of the average CL of the pooled individuals. Respective Student's t-tests were performed to test both null hypotheses of equal SW and equal quantity of OM in both morphs. When required, assumptions of normality and homoscedasticity were previously tested with Kolmogorov-Smirnov and Bartlett's tests, respectively (Sokal \& Rohlf 1995).

\section{IDENTIFICATION AND OCCURRENCE OF PREY}

Forty 'gregaria' (20 females and 20 males) and 40 'subrugosa' (22 females and 18 males) fixed in formalin were dissected and their stomachs removed. Contents were transferred to Eppendorf tubes with $1 \mathrm{ml}$ of $4 \%$ formalin seawater, until their microscopic inspection.

Relatively large food items were identified to the lowest taxonomic level under a binocular microscope at $20 \mathrm{x}$ magnification. The importance of different food components in the diet of 'gregaria' and 'subrugosa' was estimated in two different ways: the relative abundance (RA) and the frequency of occurrence (FO). RA of each food item was calculated as reported by Romero et al. (2004). Two $0.4 \mathrm{ml}$ sub-samples of the stomach content were mounted on slides and examined under a binocular microscope at 100x magnification. The occurrence of each item was recorded with an ocular grid divided in 25 squares. From each slide, 3 randomly selected fields were examined giving a total number of 150 squares for each animal. RA was calculated as:

$$
\mathrm{RA}=\mathrm{i}_{\mathrm{a}} \cdot \sum_{\mathrm{i}}^{-1} \cdot 100
$$

where $i_{a}$ is the number of squares occupied by item a and $\Sigma_{\mathrm{i}}$ is the number of squares occupied by all items.

Student's t-tests for independent samples or MannWhitney tests were used to test the null hypotheses of equal RA of relevant food items between morphs depending on whether variables had a normal distribution or not, respectively (Sokal \& Rohlf 1995).

FO of each item was calculated as:

$$
\mathrm{FO}=\mathrm{N}_{\mathrm{i}} \cdot \mathrm{N}_{\mathrm{t}}^{-1} \cdot 100
$$

where $\mathrm{N}_{\mathrm{i}}$ is the number of stomachs with item $\mathrm{i}$ and $\mathrm{N}_{\mathrm{t}} \mathrm{is}$ the total number of stomachs. Chi-square tests were used for testing the null hypothesis of homogeneity in the 
number of stomachs that presented a particular item in both morphs (Sokal \& Rohlf 1995).

The degree of diet overlap was calculated using the Pianka index (Pianka 1974) as follows:

$$
O_{j k}=O_{k j}=\frac{\sum_{i}^{n} p_{i j} p_{i k}}{\sqrt{\sum_{i}^{n} p_{i j}{ }^{2} \sum_{i}^{n} p_{i k}{ }^{2}}}
$$

where $p_{\mathrm{ij}}$ and $p_{\mathrm{ik}}$ are the frequencies of occurrence $\left(\mathrm{N}_{\mathrm{ij}} \cdot \mathrm{N}_{\mathrm{t}}^{-1}\right.$ or $\left.\mathrm{N}_{\mathrm{ik}} \cdot \mathrm{N}_{\mathrm{t}}^{-1}\right)$ of the ith resource in the stomach contents of the jth and $k$ th morph. The index varies between 0 , when there is no dietary overlap, to 1 when the overlap is complete. Overlap is considered to be biologically significant when the index is higher than 0.60 (Navia et al. 2007).

\section{CALORIMETRIC Determinations}

To compare the energetic storage in the hepatopancreas of both morphs, crabs (34 'gregaria' and 28 'subrugosa') were dissected and their hepatopancreas removed. After obtaining the DM, samples were ground and burnt in a calorimeter Parr model 1425. The values obtained were corrected for ash and acid content and were expressed as $\mathrm{kJ} \cdot \mathrm{g}^{-1}$ ash free dry mass (AFDM). Energy values were calculated using standard equations (Parr Instrument Co. 1993) ${ }^{1}$. A Student's t-test was used to test the null hypothesis of equal energetic storage between morphs.

\section{Stable Isotopes Analyses}

Around $30 \%$ of the stomach content of 'subrugosa' is composed of POM of unknown origin (Romero et al. 2004). The presence of fractions of vascular plants in the stomachs of 'subrugosa' (Romero et al. 2004), the high input of foliage of the beech forest -principally the deciduous Nothofagus pumilio- from around the Beagle Channel, and the fact that the Beagle Channel constitutes a semi-closed basin (Antezana 1999), suggest that in the Beagle Channel an important part of the organic carbon of the benthic POM has a terrestrial origin. Hence, the morph that is better adapted to deposit feeding will reflect a greater content of terrestrially-derived material in its diet. The use of stable isotopes of nitrogen and carbon $\left(\delta^{15} \mathrm{~N}:{ }^{15} \mathrm{~N} /{ }^{14} \mathrm{~N}\right.$ and $\delta^{13} \mathrm{C}:{ }^{13} \mathrm{C} /{ }^{12} \mathrm{C}$ ) has proved to be effective in estimating the trophic position, and tracing the ultimate sources of assimilated carbon for different marine organisms, respectively (e.g., Kaehler et al. 2000, Gurney et al. 2001,
Nyssen et al. 2002, Post 2002, Fredriksen 2003). In mysids, the isotopic composition of the muscle mirrors the diet over the last six to eight weeks for $\delta^{15} \mathrm{~N}$ and more than 3 months for $\delta^{13} \mathrm{C}$, and therefore gives an indication of longer term food sources (Gorokhova \& Hasson 1999, Mulkins et al. 2002).

Animals were dissected and the abdominal muscle removed. Samples were rinsed with distilled deionized water and dried at $60^{\circ} \mathrm{C}$. Muscle was ground using a mortar and pestle and stored in acid-washed glass bottles. Five pools of 15 individuals of each morph were used for stable isotopes analyses. All samples were sent to the Stable Isotopes Facility, University of California Davis, to determine $\delta^{15} \mathrm{~N}$ and $\delta^{13} \mathrm{C}$ signatures by mass spectrometry. Student's t-tests for independent samples were performed to determine whether $\delta^{15} \mathrm{~N}$ and $\delta^{13} \mathrm{C}$ were significantly different between morphs (Sokal \& Rohlf 1995).

\section{Results}

STOMACH REPLETION, QUANTITY OF INGESTED FOOD AND CONTENT OF ORGANIC MATTER

The RI pattern was similar between morphs (Fig. 1). Both morphs presented a similar percentage of stomachs at least $50 \%$ full (RIs 3 and 4 ). The quantity of ingested food

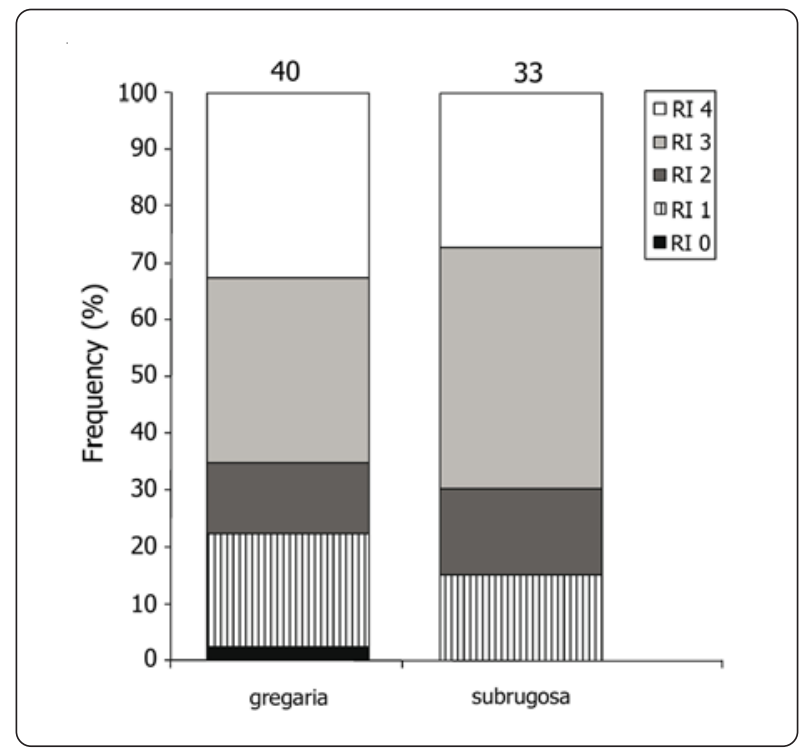

Figure 1. Stomach repletion indexes (RI) of Munida gregaria morphs 'gregaria' and 'subrugosa'. Numbers above bars indicate sample sizes / Índices de repleción estomacal (RI) de los morfos de Munida gregaria 'gregaria' y 'subrugosa'. Los números sobre las barras indican el tamaño de la muestra

1Parr Instrument Company. 1993. 1672 thermometer. Operating instruction manual. Illinois, USA. 
and organic matter (OM) in the stomach contents of both morphs was similar (Table 1). Only 'gregaria’ presented one individual with an empty stomach (Fig. 1).

\section{IDENTIFICATION AND OCCURRENCE OF PREY}

In the present study we identified 22 different items in the diet of both morphs of Munida gregaria from the Beagle Channel (Table 2). Both morphs fed mainly on crustaceans, small macroalgae, sediment and POM. Particularly, sediment and POM were found in almost all contents, with frequencies of occurrence (FO) $\geq 97.5$ (Table 2). The FO of crustaceans was similar in both morphs, whereas the FO of total algae was significantly higher in stomachs of 'gregaria' than in those of 'subrugosa' (Table 2). Unicellular preys such as foraminiferans, diatoms and radiolarians were among the most frequent food items, yet their relative abundances were low (Table 2 and 3). Radiolarians and diatoms presented a significantly higher FO in stomachs of 'gregaria' than in those of 'subrugosa' (Table 2).

As RA concerns, POM, crustaceans, sediment and algae were the main items in the stomach contents of both morphs (Table 3). The RAs of POM and sediment were similar in both morphs. In particular, the RA of 'total crustaceans' was significantly higher in 'subrugosa' than in 'gregaria'. By contrast, this situation was inverted for the total algal ingestion: 'gregaria' showed a significantly higher value of RA than 'subrugosa' (Table 3). Regarding unicellular preys, although the mean RA of radiolarians was low, probably due to their small sizes and therefore their low probability of occupying more than one square of the grid, radiolarians were significantly more abundant in stomachs of 'gregaria' than in those of 'subrugosa'
(Table 3). We could determine the presence of fragments of Munida spp. in 5\% of the stomachs of 'subrugosa' (Table 2 ). In the case of 'gregaria', we could not confirm the existence of cannibalism, however, a low proportion of the ingested crustaceans could not be identified, and hence we cannot discard the possibility that 'gregaria' also predates on individuals of the same species. Finally, a biologically significant overlap was found in the trophic niche of the 'gregaria' and 'subrugosa' morphs of $M$. gregaria $\left(O_{j k}=O_{k j}=0.88\right)$.

\section{Calorimetric Determinations and Stable Isotopes} Analyses

The energetic content of the hepatopancreas of individuals of the morph 'subrugosa' was significantly higher than that of 'gregaria' (Table 1 ). The values of $\delta^{15} \mathrm{~N}$ were similar for both morphs, whereas values of $\delta^{13} \mathrm{C}$ were significantly different between morphs (Table 1).

\section{Discussion}

The dietary overlap between 'gregaria' and 'subrugosa' morphs of Munida gregaria from the Beagle Channel was high. Both morphs presented the same simultaneous and complementary feeding habits reported by Romero et al. (2004) for M. gregaria morph 'subrugosa': predators and deposit feeders. As predators, they both fed mainly on crustaceans and algae, and as deposit feeders they ingested POM and organisms associated with the superficial layer of the sediment, such as foraminifera, diatoms and radiolarians. Furthermore, the analysis of stable isotopes of nitrogen revealed that 'gregaria' and 'subrugosa' occupy the same trophic position in the food web of the Beagle Channel.

Table 1. Results of Student' $s$ t-tests to compare different trophic variables (mean \pm standard deviation, $X \pm$ SD) between Munida gregaria morphs 'gregaria' and 'subrugosa' / Resultados de las pruebas de t de Student para comparar las diferentes variables tróficas (media \pm desviación estándar, $X \pm S D$ ) entre los morfos de Munida gregaria 'gregaria' y 'subrugosa'

\begin{tabular}{lccr}
\hline Variables & $\begin{array}{c}\text { 'gregaria' } \\
\mathrm{X} \pm \mathrm{SD}\end{array}$ & $\begin{array}{c}\text { 'subrugosa' } \\
\mathrm{X} \pm \mathrm{SD}\end{array}$ & $P$ \\
\hline Ingested food $\left(\mathrm{g}_{\mathrm{IF}} \cdot \mathrm{g}_{\mathrm{DM} \text { animal }}{ }^{-1}\right)$ & $0.038 \pm 0.015$ & $0.042 \pm 0.012$ & 0.18 \\
Organic matter $\left(\mathrm{mg}_{\mathrm{OM}} \cdot \mathrm{g}_{\mathrm{DM} \text { animal }}{ }^{-1}\right)$ & $5.51 \pm 2.03$ & $6.66 \pm 2.17$ & 0.07 \\
Energetic content $\left(\mathrm{kJ} \cdot \mathrm{g}_{\mathrm{DMFA} \text { animal }}{ }^{-1}\right)$ & $25.64 \pm 2.55$ & $27.19 \pm 2.18$ & $<0.01$ \\
$\delta^{15} \mathrm{~N}(\%)$ & $13.00 \pm 0.18$ & $13.03 \pm 0.12$ & 0.73 \\
$\delta^{13} \mathrm{C}(\%)$ & $-16.57 \pm 0.14$ & $-15.96 \pm 0.08$ & $<<0.01$ \\
\hline
\end{tabular}


Table 2. Comparison of the frequency of occurrence, by a Chi-square test, of the food items in the diet of Munida gregaria morphs 'gregaria' and 'subrugosa'. P: probability of rejecting the null hypothesis of homogeneity between morphs in the number of stomachs that presented a relevant item / Comparación de la frecuencia de ocurrencia, por medio de la prueba de Chi-cuadrado, de los ítems alimentarios en la dieta de los morfos de Munida gregaria 'gregaria' y 'subrugosa'. P: probabilidad de rechazar la hipótesis nula de homogeneidad entre los morfos en el número de estómagos que presentaron un ítem relevante

\begin{tabular}{|c|c|c|c|c|}
\hline \multirow{2}{*}{\multicolumn{2}{|c|}{ Food items }} & \multicolumn{2}{|c|}{ Frequency of occurrence (\%) } & \multirow[t]{2}{*}{$P$} \\
\hline & & 'gregaria' & 'subrugo & \\
\hline \multicolumn{2}{|l|}{ Sediment } & 100 & 97.5 & 0.792 \\
\hline \multicolumn{2}{|c|}{ Particulate Organic Matter (POM) } & 100 & 97.5 & 0.792 \\
\hline \multicolumn{2}{|l|}{ Total crustaceans } & 61 & & 0.319 \\
\hline \multicolumn{2}{|c|}{ Unidentified Crustacea } & 45 & & \\
\hline \multicolumn{2}{|l|}{ Munida spp. } & --- & & \\
\hline \multicolumn{2}{|c|}{ Amphipods/Isopods } & 25 & & \\
\hline \multicolumn{2}{|l|}{ Total algae } & 97.6 & 65 & 0.003 \\
\hline \multicolumn{2}{|c|}{ Unidentified algae } & 70 & 50 & \\
\hline \multirow[t]{2}{*}{ Chlorophyta } & Cladophora spp. & 5 & -- & \\
\hline & Chaetomorpha spp. & 27.5 & 5 & \\
\hline Phaeophyta & Sphacelaria spp. & 7.5 & 2.5 & \\
\hline \multirow[t]{3}{*}{ Rhodophyta } & Trailliella spp. & 55 & $\cdots$ & \\
\hline & Ballia spp. & 12.5 & --- & \\
\hline & Griffithsia spp. & 2.5 & 15 & \\
\hline \multicolumn{5}{|l|}{ Other } \\
\hline \multicolumn{2}{|l|}{ Foraminifera } & 67.5 & 42.5 & 0.141 \\
\hline \multicolumn{2}{|c|}{ Bacillariophyceae } & 42.5 & 12.5 & 0.020 \\
\hline \multicolumn{2}{|l|}{ Oligochaeta } & 7.5 & 17.5 & 0.585 \\
\hline \multicolumn{2}{|l|}{ Polychaeta } & --- & 5 & 0.552 \\
\hline \multicolumn{2}{|l|}{ Nematoda } & 2.5 & 10 & 0.573 \\
\hline \multicolumn{2}{|l|}{ Bivalvia } & 2.5 & --- & 0.804 \\
\hline \multicolumn{2}{|l|}{ Porifera } & 5 & --- & 0.572 \\
\hline \multicolumn{2}{|l|}{ Hydrozoa } & 10 & 10 & 1.000 \\
\hline \multicolumn{2}{|l|}{ Radiolaria } & 52.5 & 12.5 & 0.002 \\
\hline \multicolumn{2}{|c|}{ Vascular plants (Nothofagus spp.?) } & 15 & 2.5 & 0.287 \\
\hline
\end{tabular}

Some differences were found in the relative abundance of some diet items between both morphs. The relative abundance of crustaceans was higher in stomachs of 'subrugosa' than in those of 'gregaria', a higher proportion of stomachs of 'gregaria' contained more algae than in 'subrugosa', and a greater frequency of occurrence of unicellular preys was found in the diet of 'gregaria'. However, these differences in the relative abundance of some items could be due to temporal differences in sampling, since animals used for the identification of prey items in stomach contents belonging to different morphs were captured with a difference of 11 days, and within a 3 $\mathrm{km}$ distance.
Squat lobsters can display trophic specializations. For example, Pleuroncodes planipes is planktotrophic, feeding on POM, diatoms and planktonic crustaceans (AuriolesGamboa \& Perez-Flores 1997). Moreover, squat lobsters can distinguish different kinds of food, e.g., animal tissue vs. algae (Karas et al. 2007) and sort the sediment by quality rather than by size (Garm \& Høeg 2000). In order to support the hypothesis of differential exploitation of food resources we expected to observe radical differences in feeding habits: each morph feeding on either POM or preys. Therefore, we consider the differences observed between 'gregaria' and 'subrugosa' morphs of Munida gregaria in the relative abundance of some food items as indicative of 
Table 3. Mean relative abundance ( \pm standard deviation) of the food items in the diet of Munida gregaria morphs 'gregaria' and 'subrugosa', and the statistical comparisons between morphs: $\mathbf{P}$ : probability of rejecting the null hypothesis (s: Student's t-tests, $m$ : Mann-Whitney tests) / Abundancia relativa promedio ( \pm desviación estándar) de los ítems alimentarios en la dieta de los morfos de Munida gregaria 'gregaria' y 'subrugosa', y comparación estadística entre morfos: P: probabilidad de rechazar la hipótesis nula (s: pruebas de t de Student, m: prueba de Mann-Whitney)

\begin{tabular}{|c|c|c|c|c|}
\hline \multicolumn{2}{|c|}{ Food items } & \multicolumn{2}{|c|}{ Relative abundance (\%) } & \multirow[t]{2}{*}{$P$} \\
\hline & & 'gregaria' & 'subrugosa' & \\
\hline \multicolumn{2}{|l|}{ Sediment } & $20.2 \pm 10.6$ & $23.6 \pm 10.7$ & $0.08(\mathrm{~s})$ \\
\hline \multicolumn{2}{|c|}{ Particulate Organic Matter (POM) } & $33.4 \pm 16.2$ & $29.1 \pm 18.0$ & $0.13(\mathrm{~s})$ \\
\hline \multicolumn{2}{|l|}{ Total crustaceans } & $22.5 \pm 23.3$ & $39.4 \pm 24.0$ & $0.005(\mathrm{~s})$ \\
\hline \multicolumn{2}{|c|}{ Unidentified Crustacea } & $27.3 \pm 25.3$ & $39.2 \pm 22.3$ & \\
\hline \multicolumn{2}{|l|}{ Munida spp. } & -- & $42.5 \pm 58.7$ & \\
\hline \multicolumn{2}{|c|}{ Amphipods/Isopods } & $7.0 \pm 6.9$ & --- & \\
\hline \multicolumn{2}{|l|}{ Total algae } & $21.1 \pm 17.0$ & $7.4 \pm 5.6$ & $<0.001(\mathrm{~m})$ \\
\hline \multicolumn{2}{|c|}{ Unidentified algae } & $17.5 \pm 19.7$ & $6.1 \pm 2.6$ & \\
\hline \multirow[t]{2}{*}{ Chlorophyta } & Cladophora spp. & $14 \pm 9.9$ & --- & \\
\hline & Chaetomorpha spp. & $6.5 \pm 3.9$ & $8 \pm 9.9$ & \\
\hline Phaeophyta & Sphacelaria spp. & $7.6 \pm 7.4$ & $16 \pm 0.0$ & \\
\hline \multirow[t]{3}{*}{ Rhodophyta } & Trailliella spp. & $5.7 \pm 3.3$ & --- & \\
\hline & Ballia spp. & $6.0 \pm 3.0$ & --- & \\
\hline & Griffithsia spp. & $11.0 \pm 0.0$ & $6.8 \pm 3.8$ & \\
\hline \multicolumn{5}{|l|}{ Other } \\
\hline \multicolumn{2}{|l|}{ Foraminifera } & $2.7 \pm 1.2$ & $2.1 \pm 1.2$ & \\
\hline \multicolumn{2}{|c|}{ Bacillariophyceae } & $2.3 \pm 1.3$ & $2.0 \pm 0.7$ & \\
\hline \multicolumn{2}{|l|}{ Oligochaeta } & $5.0 \pm 1.0$ & $5.9 \pm 4.5$ & \\
\hline \multicolumn{2}{|l|}{ Polychaeta } & --- & $11.0 \pm 2.8$ & \\
\hline \multicolumn{2}{|l|}{ Nematoda } & $3.0 \pm 0.0$ & $3.8 \pm 1.9$ & \\
\hline \multicolumn{2}{|l|}{ Bivalvia } & $4.0 \pm 0.0$ & --- & \\
\hline \multicolumn{2}{|l|}{ Porifera } & $2.0 \pm 0.0$ & --- & \\
\hline \multicolumn{2}{|l|}{ Hydrozoa } & $5.0 \pm 1.4$ & $5.5 \pm 3.7$ & \\
\hline \multicolumn{2}{|l|}{ Radiolaria } & $2.5 \pm 1.0$ & $1.2 \pm 0.5$ & $0.008(\mathrm{~s})$ \\
\hline \multicolumn{2}{|c|}{ Vascular plants (Nothofagus spp.?) } & $5.0 \pm 3.9$ & $3.0 \pm 0$ & \\
\hline
\end{tabular}

the great variety of resources this species exploits (Nicol 1932, Karas et al. 2007, Varisco \& Vinuesa 2007), and as an evidence that $M$. gregaria is an opportunistic-generalist feeder (Garm \& Høeg 2001).

The energetic content of the hepatopancreas of the morph 'subrugosa' was higher than that of 'gregaria'. However, since the content of organic matter (Table 1) in the diet of both morphs was similar, the lower energetic content in the hepatopancreas of 'gregaria' seems not to be the result of an exclusive deposit feeding habit postulated for this morph. This difference could be a consequence of the different energetic contents of the different preys present in the diet of both morphs (Romero 2003). The energetic content of some of the potential crustacean preys that inhabit the Beagle Channel such as the amphipods of the genus Orchomenella spp. and Paramoera spp., or the isopods Exosphaeroma spp. are $20.2 \pm 1.1$ (Boy 2008); $20.8 \pm 3.5$ (Vanella 2005) and 20.3 $\pm 4.0 \mathrm{~kJ}^{-1}$ AFDM (Romero 2003), respectively; and the mean annual energetic content of the morph 'subrugosa' is $18.9 \pm 1.4 \mathrm{~kJ} \cdot \mathrm{g}^{-1}$ (Romero et al. 2006). These values are higher than those reported for macroalgae such as Macrocystis pyrifera $\left(11.5 \pm 0.1 \mathrm{~kJ} \cdot \mathrm{g}^{-1}\right.$ AFDM) $\left(\mathrm{Pérez}^{2}\right.$,

${ }^{2}$ Dr. Analía F. Pérez, Depto. de Ecología, Genética y Evolución, FCEyN - UBA, Buenos Aires, Argentina. 
pers. comm.) or Ulva spp. (16.3 $\pm 1.7 \mathrm{~kJ} \cdot \mathrm{g}^{-1}$ AFDM) (Romero 2003). Moreover, in M. gregaria morph 'subrugosa', ovaries and hepatopancreas store more energy when individuals are fed with diets of high energetic contents (Romero 2003). Thus, the differences found in the relative abundances of each of these preys in the diet of each morph could explain the higher energetic content registered in the hepatopancreas of 'subrugosa'.

Finally, the analysis of stable isotopes of carbon indicated the existence of differences between the $\delta^{13} \mathrm{C}$ between the morphs 'gregaria' and 'subrugosa'. However, the lack of information on the isotopic signatures of the food items present in the diet of $M$. gregaria hinders the possibility of making a more detailed analysis on the contribution of each source of carbon (terrestrial vs. marine) to the diet of each morph. The values of $\delta^{13} \mathrm{C}$ obtained for both morphs, though significantly different, were similar to those reported for benthic marine algae by France (1995; $\delta^{13} \mathrm{C}=-17 \pm 4 \%$ ) and Romanuk \& Levings (2005; range $\delta^{13} \mathrm{C}$ : -10 to $-18 \%$ ).

In conclusion, although some differences were found in the diet of both morphs, the degree of overlap was high: both predated on crustaceans and algae, presented a deposit feeding habit, and occupied the same trophic position. Present results do not help explain the maintenance of this polymorphism in natural populations.

\section{AcKnowledgments}

The authors would like to thank Marcelo Pérez, Marcelo Gutiérrez and Olga Florentín for field and laboratory assistance, Florencia Botto (University of Mar del Plata) for preparation of samples for stable isotope determination, and Marcela Riggio for calorimetric determinations. This project was financed by grants from the Project PNUD ARG/02/018-FMAM/BIRF 28385-AR, and Consejo Nacional de Investigaciones Científicas y Técnicas (CONICET) PIP 6187. PPB had a doctoral scholarship from CONICET while doing this study.

\section{LITERATURE CITED}

Antezana T. 1999. Hydrographic features of Magellan and Fuegian inland passages and adjacent Subantarctic waters. In: Arntz WE \& C Ríos (eds). Magellan-Antarctic: Ecosystems that drifted apart. Scientia Marina 63 (Suppl.1): 23-34.

Aurioles-Gamboa D \& R Perez-Flores. 1997. Seasonal and bathymetric changes in feeding habits of the benthic red crab Pleuroncodes planipes (Decapoda, Anomura, Galatheidae) off the Pacific Coast of Baja California Sur, Mexico. Crustaceana 70: 272-287.
Baba K, E Macpherson, GCB Poore, ST Ahyong, A Bermudez, P Cabezas, C-W Lin, M Nizinski, C Rodrigues \& KE Schnabel. 2008. Catalogue of squat lobsters of the world (Crustacea: Decapoda: Anomura families Chirostylidae, Galatheidae and Kiwaidae). Zootaxa 1905: 1-220.

Bacardit R. 1986. Larvas de Crustacea Decapoda del mar patagónico argentino, incluyendo el talud continental, adyacencias a la Tierra del Fuego e Islas Malvinas. Aspectos morfológicos, ecológicos y filogenéticos. PhD thesis, Universidad de Buenos Aires, Buenos Aires, 297 pp.

Boschi EE, CE Fischbach \& MI Iorio. 1992. Catálogo ilustrado de los crustáceos estomatópodos y decápodos marinos de Argentina. Frente Marítimo A 10: 7-94.

Boy CC. 2008. Crecimiento y reproducción de Galaxias maculatus (Teleosteii: Galaxiidae) en Tierra del Fuego, en condiciones naturales y experimentales. PhD thesis, Universidad de Buenos Aires, Buenos Aires, 183 pp.

Cartés JE. 1993. Diets of two deep-sea decapods: Nematocarcinus exilis (Caridea: Nematocarcinidae) and Munida tenuimana (Anomura: Galatheidae) on the western Mediterranean slope. Ophelia 37: 219-229.

Chilton C. 1909. Crustacea of the subantarctic islands of New Zealand. In: Chilton C (ed). The subantarctic islands of New Zealand 2: 612-613. John Mackay, Wellington.

Elner RW \& RE Lavoie. 1983. Predation on American oysters (Crassotrea virginica (Gmelin)) by American lobsters (Homarus americanus Milne-Edwards), rock crabs (Cancer irroratus Say), and mud crabs (Neopanope sayi (Smith)). Journal of Shellfish Research 3: 129-134.

France RL. 1995. Carbon-13 enrichment in benthic compared to planktonic algae: food web implications. Marine Ecology Progress Series 124: 307-312.

Fredriksen S. 2003. Food web studies in a Norwegian kelp forest based on stable isotope $\left(\delta^{13} \mathrm{C}\right.$ and $\left.\delta^{15} \mathrm{~N}\right)$ analysis. Marine Ecology Progress Series 260: 71-81.

Garm A \& JT Høeg. 2000. Functional mouthpart morphology of the squat lobster Munida sarsi, with comparison to other anomurans. Marine Biology 137: 123-138.

Garm A \& JT Høeg. 2001. Function and functional groupings of the complex mouth apparatus of the squat lobsters Munida sarsi Huus and M. tenuimana G.O. Sars (Crustacea: Decapoda). The Biological Bulletin 200(3): 281-297.

Gorokhova E \& S Hansson. 1999. An experimental study on variations in stable carbon and nitrogen isotope fractionation during growth of Mysis mixta and Neomysis integer. Canadian Journal of Fisheries and Aquatic Sciences 56: 2203-2210.

Gurney LJ, PW Froneman, EA Pakhomov \& CD McQuaid. 2001. Trophic positions of three euphausiid species from Prince Edward Islands (Southern Ocean): implications for the pelagic food web structure. Marine Ecology Progress Series 217: 167-174. 
Hendrickx ME. 2003. The temperate species of the genus Munida Leach (Crustacea, Decapoda, Galatheidae) in the east Pacific, with the description of a new species and additional records for tropical-subtropical species. Bulletin de l'Institute Royal des Sciences Naturelles de Belgique, Biologie 73: 115-136.

Kaehler S, EA Pakhomov \& CD McQuaid. 2000. Trophic structure of the marine food web at the Prince Edward Islands (Southern Ocean) determined by $\delta^{13} \mathrm{C}$ and $\delta^{15} \mathrm{~N}$ analysis. Marine Ecology Progress Series 208: 13-20.

Karas P, M Gorny \& R Alarcón-Muñoz. 2007. Experimental studies on the feeding ecology of Munida subrugosa (White, 1847) (Decapoda: Anomura: Galatheidae) from the Magellan region, southern Chile. Scientia Marina 71: 187190.

Lagerberg T. 1906. Anomura und Brachyura der Schwedischen Südpolar Expedition. Wissenschaftliche Ergebnisse der Schwedischen Südpolar Expedition 1901-1903 5(7): 6-10.

Mendoza ML \& A Nizovoy. 2000. Géneros de microalgas marinas de la Argentina, fundamentalmente de Tierra del Fuego, 142 pp. Publicación Ocasional, Centro Austral de Investigaciones Científicas, Ushuaia.

Mulkins LM, DE Jelinski, JD Karagatzides \& A Carr. 2002. Carbon isotope composition of mysids at a terrestrialmarine ecotone, Clayoquot Sound, British Columbia, Canada. Estuarine, Coastal and Shelf Science 54: 669-675.

Nakano S. 1999. Diet differentiation in polymorphic Brachymystax lenok in streams of southern Primor'e, Russia. Ichthyological Research 46(1): 100-102.

Navia AF, PA Mejía-Falla \& A Giraldo. 2007. Feeding ecology of elasmobranch fishes in coastal waters of the Colombian eastern tropical Pacific. BMC Ecology 7: 8 $<$ doi:10.1186/1472-6785-7-8>

Nicol EA. 1932. The feeding habits of the Galatheidea. Journal of the Marine Biological Association of the United Kingdom 18: 87-106.

Nyssen F, T Brey, G Lepoint, J-M Bouquegneau, C De Broyer \& P Dauby. 2002. A stable isotope approach to the eastern Weddell Sea trophic web: focus on benthic amphipods. Polar Biology 25: 280-287.

Pérez-Barros P. 2008. Evaluación del estatus taxonómico de las langostillas Munida gregaria y $M$. subrugosa (Crustacea: Decapoda: Galatheidae) de la plataforma argentina, mediante el estudio de características genéticas, reproductivas y ecológicas. $\mathrm{PhD}$ thesis, Universidad de Buenos Aires, Buenos Aires, 213 pp.

Pérez-Barros P, ME D’Amato, NV Guzmán \& GA Lovrich. 2008. Taxonomic status of two South American sympatric squat lobsters, Munida gregaria and M. subrugosa (Crustacea: Decapoda: Galatheidae), challenged by DNA sequence information. Biological Journal of the Linnean Society 94: 421-434.
Pianka ER. 1974. Niche overlap and diffuse competition. Proceedings of the National Academy of Science of the United States of America 71: 2141-2145.

Post DM. 2002. Using stable isotopes to estimate trophic position: models, methods, and assumptions. Ecology 83: 703-718.

Retamal MA. 1981. Catálogo ilustrado de los crustáceos decápodos de Chile. Gayana 44: 1-110.

Retamal MA. 2000. Decápodos de Chile. Database WB. CDseries. Biodiversity center of ETI - Springer-Verlag.[CDROM]

Romanuk TN \& CD Levings. 2005. Stable isotope analysis of trophic position and terrestrial vs. marine carbon sources for juvenile Pacific salmonids in nearshore marine habitats. Fisheries Management and Ecology 12: 113-121.

Romero MC. 2003. Hábitos alimentarios y bioenergética de la langostilla Munida subrugosa (Crustacea: Decapoda) del Canal Beagle, Tierra del Fuego, Argentina. PhD thesis, Universidad Nacional de Córdoba, Córdoba, 208 pp.

Romero MC, GA Lovrich \& F Tapella. 2006. Seasonal changes in dry mass and energetic content of Munida subrugosa (Crustacea: Decapoda) in the Beagle Channel, Argentina. Journal of Shellfish Research 25: 101-106.

Romero MC, GA Lovrich, F Tapella \& S Thatje. 2004. Feeding ecology of the crab Munida subrugosa (Decapoda: Anomura: Galatheidae) in the Beagle Channel, Argentina. Journal of the Marine Biological Association of the United Kingdom 84: 359-365.

Rosenzweig ML. 1978. Competitive speciation. Biological Journal of the Linnean Society 10: 275-289.

Skúlason S \& TB Smith. 1995. Resource polymorphisms in vertebrates. Trends in Ecology and Evolution 10(9): 366370.

Smith TB \& S Skúlason. 1996. Evolutionary significance of resource polymorphisms in fishes, amphibians, and birds. Annual Review in Ecology and Systematics 27: 111-133.

Sokal RR \& FJ Rohlf. 1995. Biometry: the principles and practice of statistics in biological research, $887 \mathrm{pp}$. WH Freeman and Company, New York.

Tapella F. 2002. Reproducción, crecimiento, distribución y abundancia de la langostilla Munida subrugosa (Anomura: Galatheidae) del Canal Beagle, Tierra del Fuego, Argentina. $\mathrm{PhD}$ thesis, Universidad Nacional de Córdoba, Córdoba, 154 pp.

Tapella F \& GA Lovrich. 2006. Morphological differences between 'subrugosa' and 'gregaria' morphs of adult Munida (Decapoda: Anomura: Galatheidae) from the Beagle Channel, southern South America. Journal of the Marine Biological Association of the United Kingdom 86: 11491155. 
Tapella F, GA Lovrich, MC Romero \& S Thatje. 2002. Reproductive biology of the crab Munida subrugosa (Decapoda: Anomura: Galatheidae) in the Beagle Channel, Argentina. Journal of the Marine Biological Association of the United Kingdom 82: 589-595.

Vanella FA. 2005. Efectos de la temperatura en el metabolismo durante el reposo, natación y alimentación. Investigación sobre la adaptación metabólica al frío en teleósteos subantárticos. PhD thesis, Universidad Nacional de Córdoba, Córdoba, 185 pp.

Varisco M \& JH Vinuesa. 2007. La alimentación de Munida gregaria (Fabricius, 1793) (Crustacea: Anomura: Galatheidae) en fondos de pesca del Golfo San Jorge, Argentina. Revista de Biología Marina y Oceanografía 42: 221-229.

Williams BG. 1973. The effect of the environment on the morphology of Munida gregaria (Fabricius) (Decapoda, Anomura). Crustaceana 24: 197-210.

Williams BG. 1980. The pelagic and benthic phases of postmetamorphic Munida gregaria (Fabricius) (Decapoda, Anomura). Journal of Experimental Marine Biology and Ecology 42: 125-141.

Recibido el 11 de marzo de 2010 y aceptado el 7 de septiembre de 2010 